\title{
フェムト秒レーザーによるコヒーレント フォノンダイナミクス
}

\author{
北島正弘・長谷宗明・Hrvoje PETEK* \\ 物質・材料研究機構 函 305-0047 茨城県つくば市千現 1-2-1 \\ * Department of Physics and Astronomy, University of Pittsburgh, 3941 O’Hara Street, Pittsburgh, PA 15260, USA
}

(2005 年 7 月 11 日受理)

\section{Coherent Phonon Dynamics Studied by fs-laser Pulses}

\author{
Masahiro Kitajima, Muneaki Hase and Hrvoje PeteK* \\ National Institute of Materials Science, 1-2-1 Sengen, Tsukuba, Ibaraki 305-0047 \\ * Department of Physics and Astronomy, University of Pittsburgh, 3941 O’Hara Street, Pittsburgh, PA 15260, USA
}

(Received July 11, 2005)

\begin{abstract}
The progress in femtosecond laser has enabled us to observe coherent motions of lattice and molecular vibrations in solids. Nevertheless the study of coherent phonons in Si, which is an important material for modern devise application, has not been made so far. We report the dynamics of transient interaction of electrons with phonons, followed by generation of coherent optical phonon, in which the pump-probe technique with $400 \mathrm{~nm}, 10 \mathrm{fs}$ laser is used for the observation. A comparison of the results is made with other semiconductors.
\end{abstract}

\section{1. は じめに}

結晶には様々な振動数と波数ベクトルを有するフォノ ンが存在する。熱励起フォノンの密度関数 $n(\omega)$ は, 系が熱平衡にある場合, プランク分布 $n(\omega)=[\exp (\hbar \omega /$ $k T)-1]^{-1}$ で与えられる。熱的に励起されたフォノンの 位相は全く乱雑である。このような時・空間的にランダ ムに振動するフォノンをインコヒーレントフォノンと呼 んでいる。したがって, 時・空間平均をとると, 個々の フォノンの動きに対応した変化は互いに相殺され, 巨視 的な物理量としての観測信号には現れない。この場合, ラマン散乱や赤外吸収等の通常の周波数領域の分光によ って研究される11。

ところで, ここにフォノンの 1 周期よりも十分短い時 間幅のパルスレーザーを照射すると, その衝撃により位 相がばらばらだったフォノンが瞬間的に一斉に励起さ れ, 時・空間的に位相の揃った振動となる。そのコヒー レントな振動は, 統計的平均を取っても相殺されず観測 可能な巨視的物理量（屈折率や分極など）の变化が引き

E-mail: kitajima.masahiro@nims.go.jp
起こされ，それがコヒーレントな応答成分して検出され る。このようにパルスレーザー励起による位相の揃った フォノンをコヒーレントフォノンと呼んでいる。超短パ ルス（ポンプ）レーザーによって発生したコヒーレント フォノンは, このパルスから $\tau$ だけ時間遅延したプロ ーブパルスにより $\tau$ の関数として応答信号を検出する 「ポンプープローブ法」により観測できる。この時間領域 におけるコヒーレント振動の測定は従来の周波数領域分 光と対比して, 時間領域分光法と呼ばれる1)。コヒーレ ントフォノンの最初の報告は誘電体物質について Nelson らによって 1979 年になされた2)。以来これまでに, 半導体, 半金属・金属, 高温超伝導体など多くの系で観 測されている。最近では半導体表面や金属上に吸着され たアルカリ金属膜3)のコヒーレント表面フォノンの検出 も行われている。固体のコヒーレントフォノンについて の測定法, およびその性質と発生・緩和の機構の詳細に ついては, 既にいくつか重要な解説書があるので1, 4, 5), 興味ある方はそれらを参照して頂きたい。

固体におけるコヒーレントフォノン分光も 2000 年頃 には成熟期に入り, 更なる高時間分解能や新しい物理現 象への挑戦へとモチベーションが変化しつつある。コヒ 
ーレントフォノン分光の利点はいうまでもなく, 直接時 間変動を観察できることである。すなわち，フォノンの 振動振幅や振動数の時間変動および位相の緩和（dephasing）を直接計測可能である。このような利点を生かし て, 例えば, 通常の振動分光によっては検出できないよ うな, フォノンの量子的特性が極短スケールの時間領域 でのコヒーレントフォノンには顕れる可能性があ $3^{6,7)}$ 。振幅制御がうまく行われれば, 大振幅フオノン の生成により非調和性フォノンダイナミクスの情報が得 られ, さらには固体の相変態や化学反応のダイナミクス の研究への応用も期待できる3，6 10)。また位相緩和時間 の決定からは, 励起キャリアとフォノンとの相互作 用11, 12) や格子欠陥による欠宿散乱などが直接議論でき

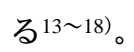

コヒーレントフォノン分光のもう 1 つ重要な利点は電 子系からのコヒーレントな応答を, フォノンからの応答 と, 同時に検出できることである。超短パルス光で励起 された電子・正孔キャリアが発生後, どのように格子と 相互作用していくかを知ることが金属・半金属, 半導体 におけるコヒーレントフォノンの生成を理解する上で必 須である。100 fs（1 fs $=10^{-15}$ 秒 $)$ 以下に現れるコヒー レントフォノン生成のダイナミクスは未知の研究領域で あり, このような光励起キャリアとフォノンとの相互作 用ダイナミクスの観測が期待できる。我々はシリコン等 の半導体において, 通常のラマン散乱分光などの周波数 領域ではなし得ない，電子系と格子系との結合による過 渡的なファノ干渉, およびそれに引き続くコヒーレント 光学フォノンの励起を観測した ${ }^{19)}$ 。本稿ではその結果を 中心に紹介する。

始めにコヒーレントフォノン生成機構のモデル, 引き 続きシリコンにおけるコヒーレントフォノン分光の現状 とファノ効果について紹介する。その後, 測定方法と観 測結果を紹介し, 最後にその物理的意義について説明す る。

\section{2. コヒーレントフォノン生成機構}

生成機構については, 現在以下のようなモデルが提案 されている：

1）瞬間的誘導ラマン散乱機構（Impulsive Stimulated Raman Scattering : ISRS) ${ }^{20)}$

誘導ラマン散乱のなかで, 特に励起光として超短パル スレーザーを用いたときの非線形光学過程を ISRS とよ ぶ。フェムト秒パルスレーザーの場合, スペクトル幅が 広いため誘導ラマン散乱の条件を満たす 2 つの周波数成 分（励起光 $\omega_{i}$ および散乱光 $\omega_{s}\left(=\omega_{i}-\omega_{q}\right), \omega_{q}$ : フォ ハン周波数）が存在するので, ポンプパルス光を照射す
ると瞬時に誘導ラマン散乱が起きてコヒーレントなフォ ノンが励起される。この場合, 原子の熱平衡位置の周り で振動が瞬間的に誘起されるので, 時間変化として sine 関数的に振る舞うと考えられる。

2）変位型励起機構（Displasive Excitation of Coherent Phonon: DECP) ${ }^{21)}$

レーザーパルスを物質に照射すると, フランクーコン ドンの原理にしたがって, 瞬時に電子が励起状態に光励 起され, その後励起状態の最も安定なエネルギー位置ま で緩和する。このとき，格子は新しい電子励起状態によ って要求される平衡位置に引きずられる。すなわち, 大 量の励起電子生成により格子周辺の遮蔽が劇的に変化す るためポテンシャルが変動する。このため, 結晶格子の 位置が瞬時に平衡位置からずれるため, 格子原子は一斉 に新しい平衡位置に向かって移動し始める。瞬間的な電 子励起により格子の平衡位置がずれるため, 振動は cosine 関数的に振る舞うと考えられる。

共鳴散乱では, 位相は非共鳴のラマン散乱から $\pi / 2$ ずれるので, やはり consine 的な振動が予想される。こ のため, DECP メカニズムは共鳴的な誘導ラマン散乱 (ISRS) で説明できるとの提案も有力である22)。

3）表面空間電荷超高速遮蔽機構（Ultrafast screening of space-charge/surface-depletion field) ${ }^{23)}$

表面空乏層, あるいは表面空間電荷層の電場が光励起 された電子-正孔対によって瞬間的に遮蔽された時に起 きる電気的衝撃が引き金となって縦波光学（LO）のコ ヒーレントフォノンが発生するとするモデルである。表 面電場が発生する極性半導体（GaAsなど）をバンドギ ヤップより高いエネルギーの光で励起した時, この機構 が働くと考えられる。この機構では DECP と同じょう に, $\mathrm{t}=0$ で平衡位置がずれるため cosine 型となる。

透明物質では実励起が伴わないので, ISRS 機構でほ とんどの場合が説明できる。一方，金属，半導体等の物 質で見られる不透明領域での励起の場合では, 物質, 励 起条件あるいは振動のモード等, 個々のケースでの励起 機構は研究されているが, 一般的な法則は必ずしも確定 されているとは言えない。

\section{3. シリコンにおけるコヒーレントフォノン 分光}

半導体シリコンは, デバイス利用性の高さから, 電子 の輸送問題 (移動度) や電子系の光応答特性（光励起キ ヤリアの緩和速度）などの研究が活発に行われている。 シリコンのような固体では, 伝導電子は結晶格子を形成 している多数のイオンに取り囲まれており, 電子の運動 状態は格子から強い影響をうける。ところが，フォノン 


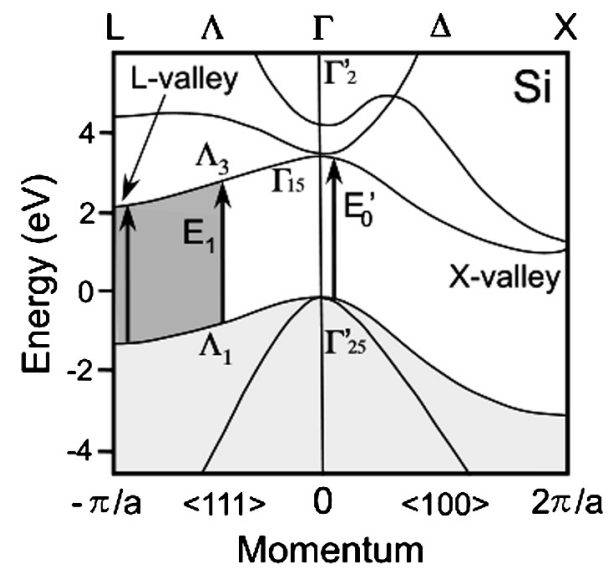

Fig. 1. Band structure of $\mathrm{Si}$ along the $\Lambda$ and $\Delta$ directions. ${ }^{31)}$ Arrows indicate vertical transitions excited with 400 $\mathrm{nm}(3.06 \mathrm{eV})$ light.

の物性, 特に電子との相互作用の研究についてはラマン 散乱測定にほとんど限定されており, コヒーレントフォ ハン分光からのアプローチはなかった。その 1 つの理由 として Si の直接遷移バンドギャップ $(3.32 \mathrm{eV}$; E0 臨界 点）と比べて, 市販のチタン・サファイアレーザーの発 振エネルギー (中心 $1.55 \mathrm{eV})$ は半分以下と小さく, し たがってコヒーレントフォノンを駆動するのに十分な光 励起キャリアが生成されないことがあげられる(Fig. 1)。 つい最近 $800 \mathrm{~nm}$ 励起によって $\mathrm{Si}$ のコヒーレントフォノ ンの観測が報告されているが信号強度が非常に小さいた め, 精密な解析までは行われていない24)。

コヒーレントフォノン生成については, 前節で述べた ようにいくつかの理論モデルが発表されている。一方, 実験的観測については, 高い感度で, かつ特に遅延時間 ゼ口付近での高い時間精度をもつ測定が要求されるた め, これまでは大半の論文ではコヒーレントフォノン生 成後の挙動が研究対象であり, 生成前の信号は全て “coherent artifact”として扱われ，議論から外されてきた。

\section{4. ファノ効果}

ファノ効果とは固体において観測される量子効果の 1 つであり, エネルギー的に離散的な準位と連続的な準 位間でおきる量子的な干渉をいう。この現象は非対称的 なスペクトル波形として観測される。分子性固体, 半導 体, ナノ量子構造体の固体系あるいは表面の問題におい ても, 周波数領域の分光学的手法を用いて広く研究され ている一般的な物理現象である。

半導体系では, 不純物ドーピングしたシリコン等にお いて, ファノ干渉に起因する光学フォノンのラマン散乱 スペクトルの非対称的な幅の広がりがよく知られてい る25)。すなわち, 格子系（離散準位）と電子系（連続準 a
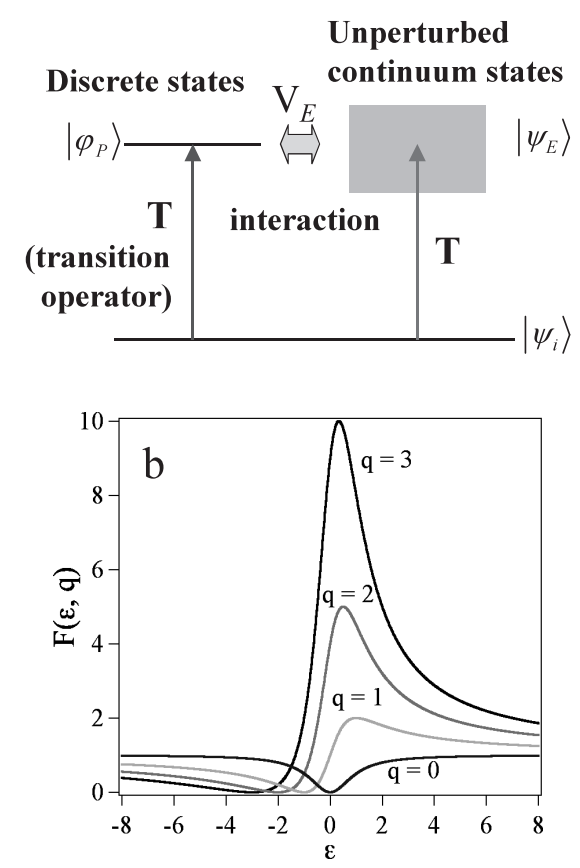

Fig. 2. (a) Fano interference of phononic discrete and electronic continuum in solid. (b) Fano line shapes calculated by using Eq. (1) for various asymmetric parameters q.

位）との間で起こるカップリングである（Fig. 2)。ファ ノ効果をより詳しく説明すると, スペクトル形状 $F(\varepsilon$, q) は25, 26),

$$
F(\varepsilon, q)=c \frac{(q+\varepsilon)^{2}}{1+\varepsilon^{2}}
$$

ここで $\varepsilon=\left(\omega-\omega_{0}-\Delta \omega\right) / \Gamma, c$ は振幅, $\omega_{0}$ はフォノ ンの周波数である。 $\Delta \omega$ と $\Gamma$ はそれぞれ周波数シフト と線幅に対応するパラメータであり，ともに格子系と電 子系との相互作用に関係する。 $q$ は $q=\frac{\left\langle\varphi_{p}|T| \psi_{i}\right\rangle}{\pi V^{*}\left\langle\psi_{E}|T| \psi_{i}\right\rangle}$ で表される非対称性パラメータであり， $\psi_{i}$ は始状態， $\psi_{E}$ は電子連続準位， $\varphi_{p}$ はこの電子準位との間のカップリ ング $V{ }^{*}{ }_{E}$ により修正されたフォノン離散準位, および $T$ は遷移演算子である。 $\varepsilon=-q$ の条件で, 反共鳴, すな わち電子系の格子系との干渉効果の結果, 両成分寄与が ちょうど打ち消しあうこと (破壊的干渉) が起きる (Fig. $2 \mathrm{~b}$ 参照）と説明される26)。

\section{5. コヒーレントフォノンの測定}

コヒーレントフォノンを検出する方法としては反射・ 透過型ポンプープローブ法, 4 光波混合法, THz 電磁波 測定法などがある。シリコンの光学フォノンの検出には, この反射型の中で, 時間分解電気-光学 (E-O) サンプ 
リング検出と呼ばれる方法を用いた（Fig. 3)。光源はパ ルス幅 $10 \mathrm{fs}$ 以下, 中心波長約 $800 \mathrm{~nm}$ のチタン・サファ イアレーザーを, BBO 結晶へ集光することにより得ら れた第 2 高調波（中心波長 $400 \mathrm{~nm}$, パルス幅約 $10 \mathrm{fs,}$ 出力約 $100 \mathrm{~mW}$ ) をもちいた。Si では $400 \mathrm{~nm}(3.06 \mathrm{eV})$ の光励起により主にブリルアンゾーン端の $L$ 点でのバ ンド間の直接遷移 $\left(\mathrm{E}_{1}=3.396 \mathrm{eV}\right)$ および $\Gamma$ 点でのバン ド間遷移 $\left(\mathrm{E}_{0}{ }^{\prime}=3.32 \mathrm{eV}\right)$ が起こると考えられる。結晶 方位との関係を調べるために, ポンプ光の偏光は $\mathrm{Si}$ [110] 結晶軸に対し平行方向 $\left(\Gamma_{25}\right)$ および $45^{\circ}$ 方向 $\left(\Gamma_{12}\right)$ に行った ${ }^{19)}$ 。

観測結果について述べる前に, E-O サンプリング法の 特徵について述べたい：試料から反射されたプローブ光 は偏光ビームスプリッターによって縦偏光成分と横偏光 成分に分離され，それぞれフォトダイオードで光電流と して検出される。それらの光電流の差から異方的な反射 率変化を信号として捉える。非線形光学特性との関係に ついて簡単に述べる。励起光との強い相互作用を受け, 試料には 2 次の非線形分極 $P_{J}^{(2)}(\tau)$ が発生する：

$$
P_{J}^{(2)}(\tau)=\chi_{j k l}^{(2)}(\tau-t) E_{k}(t) E_{l}(t)+\int_{-\infty}^{\tau} J_{j}\left(t^{\prime}\right) d t^{\prime}
$$

ここで, $\tau$ は遅延時間, 第 1 項は光整流効果の項であ り, $\chi_{j k l}^{(2)}(\tau-t)$ は 2 次の非線形感受率, および $E_{k, l}$ は ポンプ光の電場成分を表す。第二項は, キャリア移動度 の差異に起因して生じる光デンバー効果に対応する項 $\left(J_{j}\right.$ は光デンバー電流 $)$ であり, その寄与は余り大きく ない。ここで $\chi_{j k l}^{(2)}$ の中身について言及しよう。Si 結晶 の対称性よりバルクの双極子モーメントの $\chi_{j k l}^{(2)}$ への寄

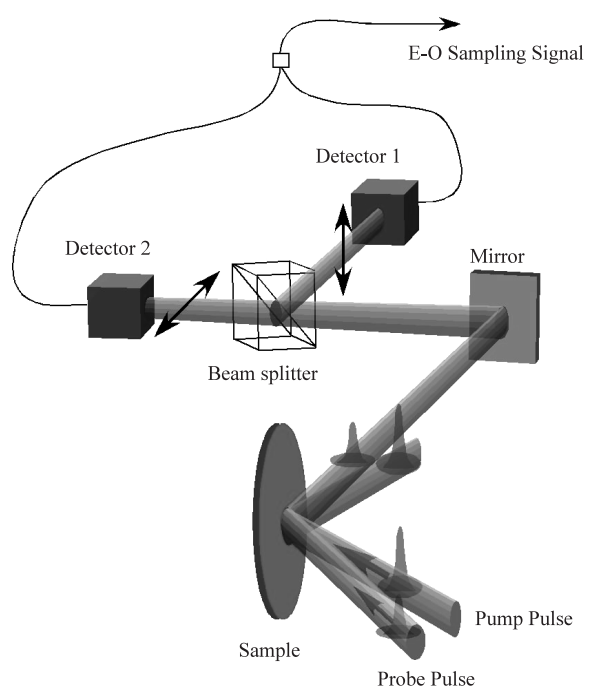

Fig. 3. The optical set-up for electro-optic (E-O) sampling measurements.
与は 0 とみなされるので, 表面の双極子モーメントおよ びバルクの 4 重極モーメントが $\chi_{j k l}{ }^{(2)}$ を支配する。本実 験のような共鳴条件で, 強く励起されるコヒーレントな 電子-正孔対とフォノンの運動が $\chi_{j k l}^{(2)}(\tau-t)$ の変動の 原因となる。E-0 サンプリングではこのような非線形分 極の変化が非等方的反射率変化として検出される。また, プローブ光の電場の影響を考慮すると, 3 次の非線形感 受率 $\chi^{(3)}$ による応答を考慮する必要がある。この場合非 線形分極は式 (2) に $\chi_{j k l m}{ }^{(3)}(\tau-t) E_{k}(t) E_{l}(t) E_{m}(t)$ (こ こで $E_{m}$ はプローブ光の電場成分）が加わる形で表現さ れるであろう19)。

\section{6. コヒーレントフォノンの観察とスペクト ル波形}

Fig. 4 は，E-O サンプリングの効果を示すために，通 常の等方的な反射率変化との違いを表わしたものであ る。 $\Delta R_{\mathrm{s}}, \Delta R_{\mathrm{p}}$ はそれぞれ，挿入図のように反射率変化 の横偏光, 縦偏光成分に相当し, 時間領域では $100 \mathrm{fs}$ 程 度で立ち上がり, その後 $1 \mathrm{ps}$ 程度で減衰している。こ れは価電子帯から伝導体に光励起された電子・正孔プラ ズマの生成と緩和に起因していると考えられる。しかし, このように等方的なキャリアのバックグランドがある と，その信号上に現れているコヒーレント信号の詳細な 解析は困難である。そこで，これらの等方的な反射率変 化の差を取った E-O サンプリング信号を見ると，上手 くキャリアのバックグランドが相殺され, コヒーレント 信号が $\mathrm{S} / \mathrm{N}$ 比良く反映された非等方的な反射率変化の みの信号が得られていることがわかる。このようにして $\mathrm{E}-\mathrm{O}$ サンプリングを行うことにより $\mathrm{Si}$ 等半導体におけ るコヒーレント信号を得ることができる。

Fig. 5 は $\Gamma_{25}$,のポンプープローブ配置（Fig. 6 （b）挿入 図）で得られた時間分解 E-O サンプリング信号の光エ ネルギー依存性である。励起光エネルギーが $2.99 \mathrm{eV}$ の

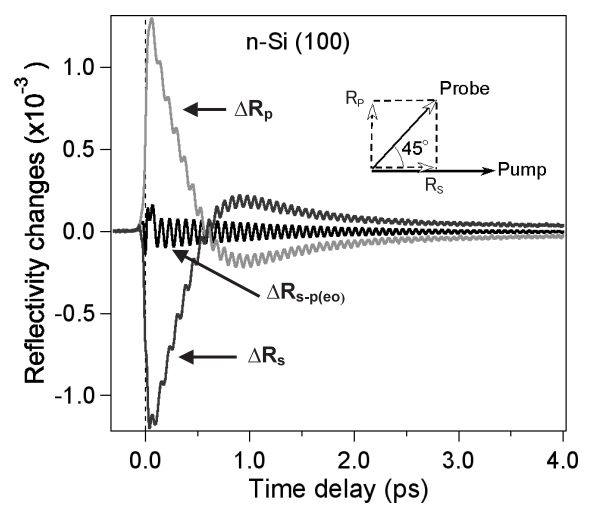

Fig. 4. The isotoropic reflectivity changes $\left(\Delta R_{\mathrm{s}}, \Delta R_{\mathrm{p}}\right)$ and E-O signal $\left(\Delta R_{\mathrm{s}-\mathrm{p}(\mathrm{eo})}=\Delta R_{\mathrm{s}}-\Delta R_{\mathrm{p}}\right)$ from $\mathrm{Si}(100)$. 


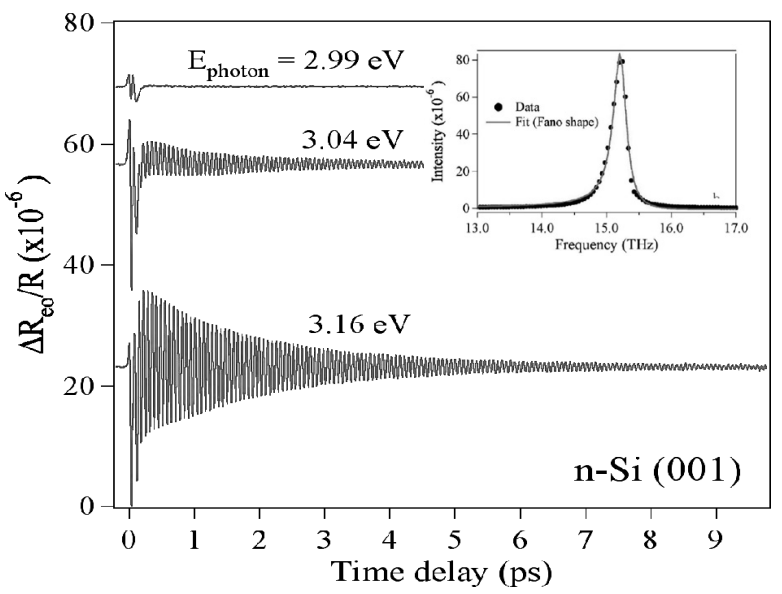

Fig. 5. The E-O signal from $\mathrm{Si}(100)$ for different pump energies. The amplitude for the observed coherent phonons increases with the pump energy. The Fourietransformed spectrum is well reproduced by Fano Fit (soild line).
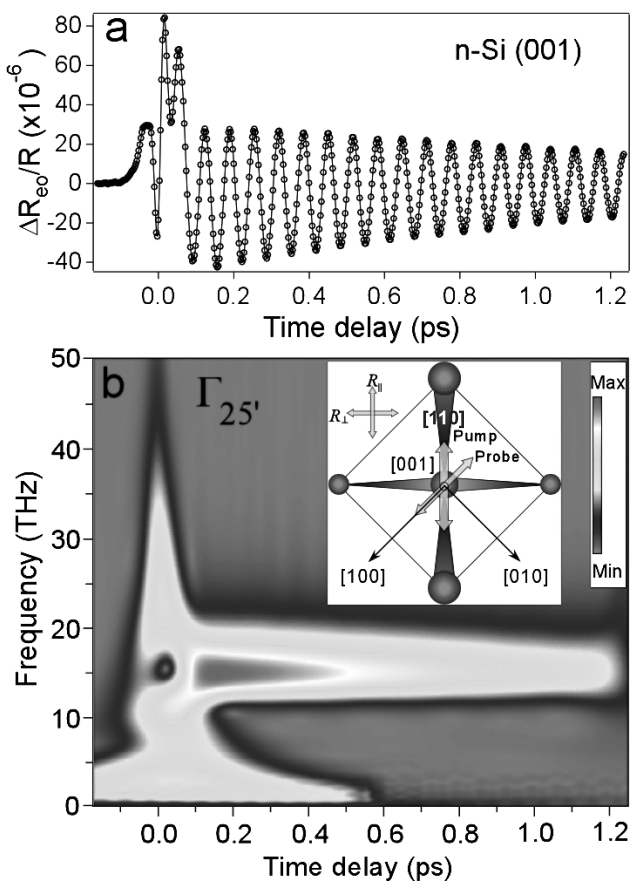

Fig. 6. (a) Transient $\mathrm{E}-\mathrm{O}$ signal for $\mathrm{n}-\mathrm{Si}(100)$ and (b) its continuous wavelet transform. The excitation is performed in the $\Gamma_{25}$, pump-probe configuration. The [001]-direction is parallel to the surface-normal (the inset in Fig. 6 (b)).

時, 電子系の非周期的応答成分のみが時間ゼロ付近に観 測される。高エネルギー側では, シリコンの光学フォノ ンに対応する約 $66 \mathrm{fs}$ の周期（周波数 $\omega_{0}=15.2 \mathrm{THz}$ ）の コヒーレントな振動成分が明瞭に現れる。フォノンの振 幅は光エネルギーが増加するとともに, 単調に増加した。 これはコヒーレントフォノンの生成が期待したように直
接光学遷移，すなわち共鳴励起により起こっていること を示している。

観測された振動は cosine 関数的時間変化を示した。 一方 $800 \mathrm{~nm}$ 励起による Si のコヒーレントフォノンは sine 関数的変化を示すと報告されている ${ }^{24)}$ 。前者の光励 起が共鳴条件で, 後者が非共鳴であることを考慮して, シリコンのコヒーレント光学フォノンの生成は誘導ラマ ン過程（ISRS）の範疇でも説明が可能である。時間領 域信号のフーリエ変換より得られた光学フォノンのスペ クトルは非対称性を示し，その形状はファノの式（1） によるフィッティングでよく再現された（Fig. 5 挿入 図)。得られたパラメータのうち, 非対称性パラメータ $q$ は-12であった。 $q$ の值が負であることの意味につい て考えてみよう。 $q$ は電子と格子間カップリングに対応 するものであり，共鳴励起の条件ではフォノンが電子と 結合する時 $q>0$, また正孔と結合する時は $q<0$ となる ベきである27)。したがって，光励起により価電子帯に生 成した正孔が伝導帯に励起された電子より強くフォノン と結合することが示唆される。

\section{7. 時間ゼロ付近での詳細：電子系と格子系 との破壊的干渉の観察}

Fig. 6 (a) は，始めの〜 1 ps までの E-O サンプリング 信号の変化である。これにより励起電子と格子間の相互 作用をより精密に見てみよう。遅延時間ゼロから $100 \mathrm{fs}$ 付近には，非常に鋭く複雑な応答が見られる。これは， 電子系からの非周期的応答と格子系からの応答とが複雑 に絡み合っている時間領域に対応する。引き続き，その 後すぐにコヒーレントフォノンによる振動が観測され る。このフォノンの時間周期は約 $66 \mathrm{fs}$ であり，ラマン 散乱分光でも観測される光学フォノンである。一方, $\mathrm{Ge}$ については，コヒーレント光学フォノンに対する Scholz らの理論 ${ }^{28)}$ によると, 光励起キャリアのうち, 正孔の逆 格子空間における非等方的な分布が変形ポテンシャルの 不均衡な変動をもたらし，これがコヒーレントフォノン 生成の駆動力となると考えられる。

このメカニズムを適用すれば，Si における Si-Si 結合 の非等方的な変動を説明することが可能である。すなわ ち，Fig. 6（b）挿入図に表すように，[110］方向に偏光 したポンプ光で試料を励起すると $\left(\Gamma_{25}\right.$, のポンプープロ 一ブ配置)，等価な 4 つの $\mathrm{Si}-\mathrm{Si}$ 結合のうち，この偏光に 平行な 2 つの結合に属する電子の夕が励起される。この ようにして瞬間的に誘起されるキャリアの分布がフオノ ンと結合し, コヒーレント光学フォノンが発生する。

一方, 試料を 45 度回転させて検出される $\Gamma_{12}$ のポン プープローブ配置では対照的な結果であった。すなわち, 
コヒーレントフォノンは励起されず，電子系からの非周 期的応答の夕観測された。この時, 励起光の偏光により 光励起される電子が属する結合は 4 つとなるため, 励起 されるキャリア分布も等方的である。したがって $\Gamma_{25}$ 配 置では生じたような非等方的なキャリア分布は生じなか ったと考えられる。

さて，単なるフーリエ変換（Fig. 5 挿入図）は時間に 対しての平均操作であるので, 電子系と格子系とが重な り合う時間ゼロ近傍で変動する複雑な応答から特異な情 報を取り出すことはできない。そこで時間領域波形を連 続ウェーブレット変換 (CWT) ${ }^{29)}$ して得られたクロノグ ラム（時間一周波数マップ）を使うと, 現象はより鮮明 に見ることができる。Fig. 6 (b) は $\Gamma_{25}$,のポンプープロ ーブ配置の場合である。時間ゼロ付近で縦方向に延びる 応答成分はホットな電子・正孔プラズマによる応答であ る。また周波数 $15 \mathrm{THz}$ 付近で横方向に延びる成分はコ ヒーレント光学フォノンである。特に注目すべきは, 遅 延時間ゼロ付近 $(22 \mathrm{fs}, 15.3 \mathrm{THz})$ に現れた穴（dip） である19)。これは, 離散準位を持つコヒーレント光学フ オノンと連続準位をもつコヒーレント電子の各々の振幅 が（反共鳴的に）打ち消し合うように干渉することを表 すと考えられる。また，これはファノの非対称関数で議 論される干渉の一部を時間分解測定したものであり, 電 子ラマン散乱における電子と格子の終状態相互作用に相 当すると考えられる。

一方， $\Gamma_{12}$ のポンプープロープ配置で得られた時間波 形のCWTには， $\Gamma_{25}$ 配置で観測された dip が観測され なかった。これは電子と格子が結合できず, コヒーレン トフォノンが励起されなかったことによる。

Fig. 6 で見てきたダイナミクスの内, $50 \mathrm{THz}$ 以上まで 周波数が広がる電子系の応答は, 既に述べたように, フ アノ干渉に寄与する一方の成分である電子系の連続準位 に対応するものであり, その主たる寄与は $L$ 点および $\Gamma$ 点での光励起により生成されるホットキャリアによる電 子ラマン散乱と考えられる（Fig. 1)。ホットキャリアの バンド内散乱がその有力な過程である (一方, 通常ラマ ンで見られるファノ干渉は熱キャリアによるものであ る)。

\section{8. 他の半導体との比較}

コヒーレント光学フォノンの励起について, 他の半導 体 $\mathrm{Ge}$ および $\mathrm{GaAs}$ と比較してみよう。 $\mathrm{Ge}$ では $\mathrm{Si}$ と同 じく, $\Gamma_{25}$,のポンプープローブ配置ではコヒーレント光 学フォノンは生成するが, $\Gamma_{12}$ のポンプープローブ配置 では全く観測されない。Geの場合, 直接遷移バンドギ ヤップは $0.66 \mathrm{eV}$ と, ポンプ光エネルギー $(3.06 \mathrm{eV})$ に

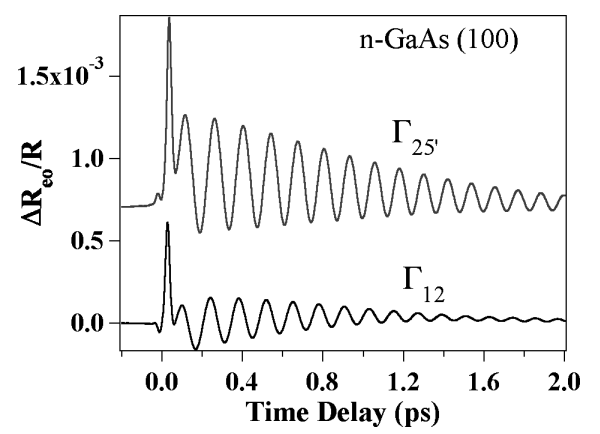

Fig. 7. Transient E-O signals for $\mathrm{n}-\mathrm{GaAs}(100)$ exited in the $\Gamma_{25}$, and $\Gamma_{12}$ pump-probe configurations.

比べて遙かに低い。したがって，共鳴から大きくはずれ るため, 実際生成するフォノンの振幅はシリコンと比べ て小さく, そのため観測された反共鳴の効果も小さい。

一方, $\mathrm{GaAs}$ の直接遷移バンドギャップは $1.47 \mathrm{eV}$ で あり, この場合も光エネルギーより小さく $\Gamma$ 点での $E{ }^{\prime}{ }_{0}$ 遷移は共鳴的ではない。ところが $L$ 点でエネルギーギ ヤップは $3.1 \mathrm{eV}$ とほぼ光エネルギーに等しく, 共鳴励 起 $\left(E_{1}\right.$ 遷移) は十分に起き得る。そのため, 強いコヒ ーレントLO フォノンの励起が観測される（Fig. 7)。し たがって, 時間ゼロ近傍にはシリコンで見られたような 反共鳴による破壊的干渉も観察された。GaAs のコヒー レントフォノン励起は $\mathrm{Si}$ や $\mathrm{Ge}$ とは異なる。すなわち, これらの半導体では励起されない $\Gamma_{12}$ ポンプープローブ 配置でも, 光学フォノンによるコヒーレントな応答が観 測される（フォノン振幅は $\Gamma_{25}$ 配置と比べると小さい が)。GaAs のコヒーレントフォノンの生成については, これまでよく研究されており23,30), 表面空間電荷の超 高速遮蔽機構に基づき議論されてきた。観察された $\Gamma_{12}$ 配置の励起はこの機構によるものと思われる。すなわち GaAs ではホットキャリアの非等方的な分布による変形 ポテンシャルの変動に加えて, LO フォノン振動が電気 分極を誘起するフレーリヒ型の電子・格子相互作用 ${ }^{31)}$ の 寄与が大きいことが示唆される（ $\Gamma_{25}$ 配置では変形ポテ ンシャル相互作用とフレーリヒ相互作用が同時に働く)。

\section{9.おわりに}

本稿では, これまでフェムト秒レーザーパルス幅の中 に埋もれていた電子と格子の間で起きる相互作用ダイナ ミクスについて, コヒーレントフォノン生成機構やファ ノ干渉と関連させて説明した。時間-周波数領域で観測 された dip が示すものは, 光励起で生成されたホットな 電子・正孔プラズマが結晶格子に力を及ぼし, 結晶格子 を形成している原子集団の運動が一斉に開始される瞬間 である（Fig. 8)。別の見方をすれば，電子と格子は別々 


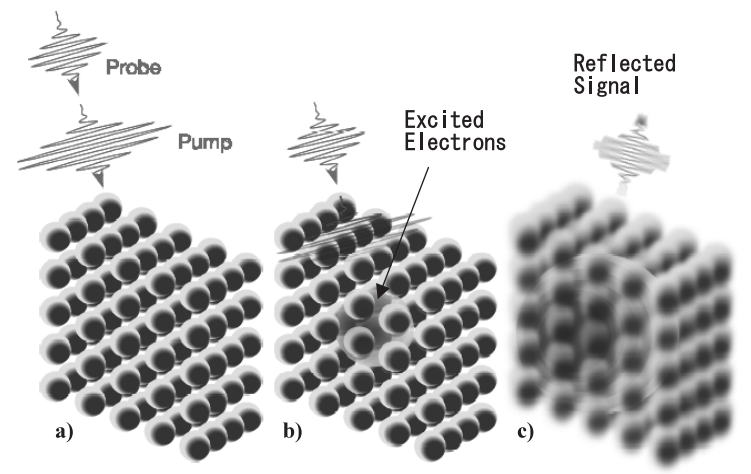

Fig. 8. A schematics of interactions between the excited electrons and the lattice atoms: a) Before excitation by pump laser pulse, the lattice contains few free electrons, and atoms in the crystal lattice are virtually at rest. b) The pump creates a localized cloud of excited electrons, which interacts with surrounding lattice and causes characteristic vibrations. c) This is described in terms of the generation of quasiparticles (coherent phonons).

の存在として振る舞うのではなく, 強い相互作用により 互いにまといつかれながら（dressed）一体となって運動 する準粒子（この場合はコヒーレント光学フォノン）の 誕生する瞬間が観察されたと言える。また, コヒーレン 卜光学フォノンの生成は電子・フォノン相互作用（変形 ポテンシャル相互作用およびフレーリヒ相互作用）によ って誘起され, その応答は物質のバンド構造や電気分極 などに強く左右される。紙面の関係で紹介しなかったが, フォノンのコヒーレント制御および超短時間領域におけ るコヒーレントフォノンの量子性などに関する研究も興 味あるところであり, 今後の一層の発展が期待される。

\section{文献}

1) 中島信一, 長谷宗明, 溝口幸司, 播磨 弘 : 表面科 学 19,64 (1998).

2) K.A. Nelson, D.D. Dlott and M.D. Fayer: Chem. Phys. Lett. 64, 88 (1979).

3) K. Watanabe, N. Takagi and Y. Matsumoto: Chem Phy. Lett. 366, 606 (2002); Phys. Rev. Lett. 92, 57401 (2004).

4) 溝口幸司, 長谷宗明, 谷 正彦: “超高速光エレク トロニクス技術ハンドブック”， 7.4 節“コヒーレン トフォノン” (小林孝壽企画・監修) (リアライズ理工 センター, 2003) p 372.

5) T. Dekorsy, G.C. Cho and H. Kurz: in "Light Scattering in Solids VIII", ed. by M. Cardona and G. Guentherodt (Springer-Verlag, Berlin, Ch. 4, 2000).

6) O. Misochko, M. Hase, K. Ishioka and M. Kitajima: Phys. Rev. Lett. 92, 197401 (2004).

7) O. Misochko, M. Hase, K. Ishioka and M. Kitajima: Phys. Lett. A 321, 381 (2004).
8) M. Hase, M. Kitajima, S. Nakashima and K. Mizoguchi: Phys. Rev. Lett. 88, 0677401 (2002).

9) M. Hase, M. Kitajima, S. Nakashima and K. Mizoguchi: Phys. Rev. Lett. 93, 109702 (2004).

10) M. Hase, M. Kitajima, S. Nakashima and K. Mizoguchi: Appl. Phys. Lett. 83, 4921 (2003).

11) M. Hase, K. Mizoguchi, H. Harima, S. Nakashima and K. Sakai: Phys. Rev. B 58, 5448 (1998).

12) M. Hase, K. Ishioka, J. Demsar, K. Ushida and M. Kitajima: Phys. Rev. B 71, 184301 (2005).

13) M. Hase, K. Ishioka, M. Kitajima and K. Ushida: Appl. Phys. Lett. 76, 1258 (2000).

14) K. Ishioka, M. Hase, M. Kitajima and K. Ushida: Appl. Phys. Lett. 78, 3965 (2001).

15) M. Hase, K. Ishioka, M. Kitajima and K. Ushida: Appl. Phys. Lett. 82, 3668 (2003).

16) 石岡邦江, 長谷宗明, 北島正弘, 丑田公規 : 表面科 学 24, 288 (2003).

17) M. Kitajima, M. Hase, K. Ishioka and K. Ushida: Nucl. Instrum. Methods 206, 99 (2003).

18) K. Ishioka, M. Hase and M. Kitajima: Solid State Commun. 130, 327 (2004).

19) M. Hase, M. Kitajima, A.M. Constantinescu and H. Petek: Nature 426, 51 (2003).

20) Y-X. Yan, E.B. Gamble and K. Nelson: J. Chem. Phys. 83, 5391 (1985); Y-X. Yan and K. Nelson: J. Chem. Phys. 83, 6240 (1987).

21) H.J. Zeiger, J. Vidal, T.K. Cheng, E.P. Ippen, G. Dresselhaus and M.S. Dresselhaus: Phys. Rev. B 45, 768 (1992).

22) G.A. Garrett, T.E. Albrecht, J.F. Whitaker and R. Merlin: Phys. Rev. Lett. 77, 3661 (1996).

23) T. Pfeifer, T. Dekorsy, T. Kütt and H. Kurz: Appl. Phys. A 55, 482 (1992); T. Dekorsy, T. Pfeifer, W. Kütt and H. Kurz: Phys. Rev. B 47, 3842 (1993).

24) A.J. Sabbah and D.M. Riffe: Phys. Rev. B 66, 165217 (2002).

25) F. Cerdeira, T.A. Fjeldly and M. Cardona: Phys. Rev. B 8, 4734 (1973).

26) U. Fano: Phys. Rev. 124, 1866 (1961).

27) T.E. Stevens, J. Kuhl and R. Merlin: Phys. Rev. B 65, 144304 (2002).

28) R. Scholz and A. Stahl: Phys. Stat. Sol. (b) 173, 199 (1992).

29) ウェーブレットとは周波数が時間とともに変動する 信号を時間と周波数の両面から捉えるための時間周 波数解析法の 1 つであり, 近年急速に発展した数学 的手法である。参考書として, 例えば, 榊原 進 : “ウエーブレットビギナーズガイド” (東京電機大学 出版局, 1998).

30) A.V. Kuznetzov and C.J. Stanton: Phys. Rev. Lett. 73, 3243 (1994)

31) P.Y. Yu and M. Cardona: "Fundamentals of Semiconductors” (Springer-Verlag, Berlin, Heidelberg, 1996); “半導 体の基礎” 末元 徹他訳 (シュプリンガーフェアラ 一ク東京, 1999). 